\title{
HYDROLYTIC POTENTIAL OF A PSYCHROTROPHIC PSEUDOMONAS ISOLATED FROM REFRIGERATED RAW MILK
}

\author{
Ana Paula F. Corrêa, Daniel J. Daroit, Renata V. Velho, Adriano Brandelli*
}

Laboratório de Bioquímica e Microbiologia Aplicada, Departamento de Ciência de Alimentos, Universidade Federal do Rio Grande do Sul, Porto Alegre, RS, Brasil.

Submitted: May 04, 2010; Approved: May 23, 2011.

\begin{abstract}
The production of extracellular hydrolases by a psychrotrophic bacterium isolated from refrigerated raw milk, and identified as a Pseudomonas sp. belonging to the Pseudomonas jenssenii group, was studied. This bacterium produced proteolytic and lipolytic enzymes in all media investigated (skim milk, cheese whey, casein broth, and tryptone soy broth). High levels of $\alpha$-glucosidase were produced in skim milk broth. Hydrolytic enzymes detected in skim milk broth are of particular concern, indicating that these enzymes could be produced by Pseudomonas sp. during the cold storage of raw milk, contributing to the spoilage problem in milk and dairy products.
\end{abstract}

Key words: Pseudomonas; hydrolases; protease; lipase; glycosidase

Food spoilage results in high economical impacts to the food industry, and microbial activity is the most common cause of this. The microbiota colonizing a particular food depends on the product characteristics and how it is processed and stored. Spoilage is most rapid in proteinaceous foods such as milk and dairy products, since these are highly nutritious, possess nearneutrality $\mathrm{pH}$ values and high moisture content, thus allowing the growth of a wide range of microorganisms $(9,12)$. Milk normally acquires contaminating bacteria during milking, handling and processing (3).

The cold storage of raw milk and dairy products is a prerequisite for the dairy industry. Although such practice on farms and in processing plants reduces the spoilage by mesophilic microorganisms, it will not prevent deterioration by psychrotrophic microorganisms (12,26). Therefore, psychrotrophic microorganisms are predominant in raw milk microbiota during the storage, producing hydrolytic enzymes such as proteases and lipases which are responsible for many quality issues, defects and deterioration, resulting in the limited shelf-life of dairy products $(3,20)$. Although psychrotrophs are usually destroyed by heat treatments, the extracellular enzymes produced by these microorganisms are usually thermostable, keeping their activities even after pasteurization and even ultrahigh temperature (UHT) treatments $(8,25)$. Enzymatic spoilage without concomitant bacterial growth is of special concern in UHT milks (26).

Pseudomonas spp. are the predominant psychrotrophic bacteria isolated from refrigerated raw milk, being among the major spoilage agents in the dairy industry $(8,20)$. The aim of this study was to investigate the profile of extracellular 
hydrolases produced by a psychrotrophic pseudomonad isolated from refrigerated raw milk.

The strain 1A4R was isolated from refrigerated raw milk in Plate Count Agar (PCA; Mast Diagnostics, Merseyside, UK) after 7 days at $7^{\circ} \mathrm{C}(21)$, and selected by producing large clearing zones on skim milk agar (SMA) plates (24). Cultures routinely maintained on SMA at $4^{\circ} \mathrm{C}$ were subcultured periodically. For inoculum preparation, the isolate was inoculated on SMA plates and incubated at $30^{\circ} \mathrm{C}$ for $24 \mathrm{~h}$. The cultures were gently scraped from the agar surface, added to a sterile solution of $0.85 \%(\mathrm{w} / \mathrm{v}) \mathrm{NaCl}$ and mixed until a homogeneous suspension with O.D.600 of 0.5 was obtained.

Bacterial identification was conducted based on morphological and biochemical tests $(11,14)$, and sequence of the $16 \mathrm{~S}$ rDNA. DNA was extracted from overnight cultures using the Promega Wizard SV Genomic DNA kit (Promega Corp., Madison, WI, USA). The amplification of 16S rDNA by PCR with the specific primers 27f (5'-GAGTTTGATCCTGG CTCAG-3') and 1525r (5'-AGAAAGGAGGTGATCCAGCC3') was conducted using a Mastercycler® Personal Eppendorf (Eppendorf AG, Hamburg, Germany). PCR product was sequenced in the ACTGene Laboratory (Centro de Biotecnologia, UFRGS, Porto Alegre, Brazil) using the automatic sequencer ABI-PRISM 3100 Genetic Analyzer armed with $50 \mathrm{~cm}$ capillaries and POP6 polymer (Applied Biosystems, Foster City, CA, USA). Sequencing data were collected using the software Data Collection v1.0.1 (Applied Biosystems). The BLAST algorithm was used to retrieve for homologous sequences in GenBank (http://www.ncbi.nlm. nih.gov) using the software CLUSTAL W (27). The 16S rDNA sequence obtained for Pseudomonas sp. 1A4R has been submitted to GenBank under the accession number HM173665.

The phenotypical characteristics indicate the isolate belongs to the genus Pseudomonas (11), being mostly equivalent to Pseudomonas asplenii and Pseudomonas jenssenii (28). The 16S rDNA sequencing data indicated that the strain was taxonomically close to Pseudomonas species.
The sequence shared $99 \%$ of similarity with Pseudomonas koreensis (13), which clusters with P. jenssenii (28). According to these characteristics the isolate was identified as a Pseudomonas sp. belonging to the $P$. jenssenii group. Strains of the $P$. jenssenni cluster have not been associated to milk spoilage, which is frequently related to Pseudomonas fluorescens, Pseudomonas putida and Pseudomonas fragi as prevalent species $(17,19,29)$.

Production of extracellular enzymes (protease, lipase and glycosidases) was carried out by submerged (shaked-flask) cultivations using casein (C10B, $10 \mathrm{~g} / \mathrm{L}$; C50B, $50 \mathrm{~g} / \mathrm{L})$, cheese whey powder (CWPB; $10 \mathrm{~g} / \mathrm{L})$ or UHT skim milk (SMB; 10 $\mathrm{mL} / \mathrm{L})$ as substrates in mineral medium $\left(2 \mathrm{~g} / \mathrm{L} \mathrm{KH}_{2} \mathrm{PO}_{4}, 7 \mathrm{~g} / \mathrm{L}\right.$ $\mathrm{K}_{2} \mathrm{HPO}_{4}, 0.2 \mathrm{~g} / \mathrm{L} \mathrm{CaCl}_{2}$ and $0.2 \mathrm{~g} / \mathrm{L} \mathrm{MgSO}_{4}$ ). Tryptone soy broth (TSB) was also evaluated. The initial $\mathrm{pH}$ of the media was adjusted to 7.0 before sterilization. Erlenmeyer flasks containing $50 \mathrm{~mL}$ of medium were inoculated with $500 \mu \mathrm{L}$ $(1 \%, v / v)$ of a bacterial suspension and incubated at $30^{\circ} \mathrm{C}$ in an orbital shaker $(125 \mathrm{rpm})$ for $48 \mathrm{~h}$. After this period the culture media were centrifuged $(10,000 \times g$ for $10 \mathrm{~min})$, and supernatants were utilized as enzyme source.

Extracellular protease activity was estimated using azocasein (Sigma, St. Louis, MO, USA) as substrate (24). One unit (U) of protease was defined as the amount of enzyme that caused an increase of 0.1 absorbance unit at the defined assay conditions.

Lipase activity was evaluated using $p$-nitrophenylpalmitate ( $p$ NPP; Sigma) as substrate (3). Substrate solution was prepared with $1 \mathrm{~mL}$ of $p$ NPP $(0.4 \mathrm{mg} / \mathrm{mL})$ dissolved in isopropanol and $9 \mathrm{~mL}$ of Tris- $\mathrm{HCl}$ buffer (100 mM; pH 7.0) containing Triton X-100 (0.04\%, v/v) and arabic gum $(0.11 \%$ $\mathrm{w} / \mathrm{v})$. The reaction $(1 \mathrm{~mL})$ contained $800 \mu \mathrm{L}$ of substrate solution and $200 \mu \mathrm{L}$ of enzyme sample. After incubation at 37 ${ }^{\circ} \mathrm{C}$ for $60 \mathrm{~min}$, the release of $p \mathrm{NP}$ was determined at $405 \mathrm{~nm}$. One unit $(U)$ of lipase was defined as the amount of enzyme that released $1 \mu \mathrm{mol}$ of $p \mathrm{NP}$ at the above conditions.

Activities of $\alpha$-glucosidase, $\beta$-glucosidase, $\alpha$ - 
galactosidase, $\beta$-galactosidase, $\mathrm{N}$-acetyl- $\beta$-glucosaminidase and $\mathrm{N}$-acetyl- $\beta$-galactosaminidase were evaluated using the respective $p$ NP-derivatives (Sigma) as substrates (4). Release of $p$ NP was determined by measuring the absorbance at 405 $\mathrm{nm}$, and one unit (U) of glycosidase was defined as the amount of enzyme that released $1 \mu \mathrm{mol}$ of $p \mathrm{NP}$ at the assay conditions.

The profile of extracellular enzymes (protease, lipase, glycosidases) produced by Pseudomonas sp. 1A4R during growth on different media is presented in Table 1. Preliminary results showed the proteolytic potential of strain $1 \mathrm{~A} 4 \mathrm{R}$ during growth on skim milk agar plates, where prominent clearing zones were observed (data not shown). Subsequently, protease production was investigated in submerged cultivations. Extracellular proteolytic activities of Pseudomonas 1A4R were higher on TSB, followed by CWPB, C50B, SMB and C10B (Table 1). During growth on casein broths, which contained this substrate as the only carbon and nitrogen source, protease production showed to be positively correlated with the casein content, suggesting that casein could act as an inducer of protease production in Pseudomonas 1A4R.

Table 1. Extracellular enzyme activities produced by Pseudomonas sp. during growth on different media $\dagger$

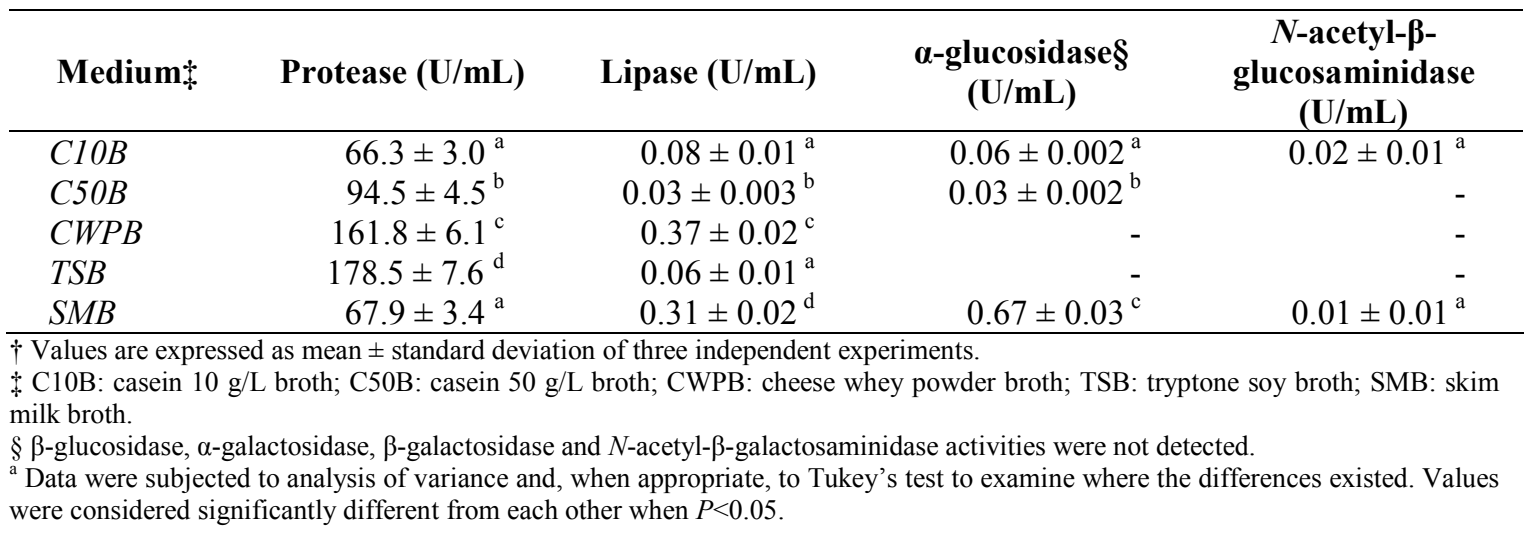

Extracellular protease production was also evaluated by gelatin zymograms. Culture supernatants were electrophoresed on $16 \%$ polyacrylamide gels containing $1 \mathrm{mg} / \mathrm{mL}$ gelatin. After electrophoresis, gels were washed twice with $20 \mathrm{mM}$ Tris- $\mathrm{HCl}$ buffer ( $\mathrm{pH} 8.0$ ) containing 2.5\% (v/v) Triton X-100 for $30 \mathrm{~min}$, and then with the same buffer without detergent for $60 \mathrm{~min}$. After $12 \mathrm{~h}$ of incubation at $30^{\circ} \mathrm{C}$ in the last buffer, gels were stained with Coomassie Brillant Blue R-250 (Sigma) and then destained. Protease bands appear as clear zones on a blue background due to gelatin hydrolysis.

On zymogram analysis, Pseudomonas 1A4R showed to produce at least one proteolytic enzyme during growth on $\mathrm{SMB}$, and at least two proteases on CWPB, TSB and casein broths (Fig. 1). Large activity zones on the zymogram were observed for proteases produced on CWPB and TSB, which may be a function of enzymes migrating in the native conformation, and/or the result of a larger amount of protease (Table 1). However, it is not clear if these proteolysis bands corresponded to different monomeric proteases or to aggregates or multimers (19). Rajmohan et al. (22) reported the production of five proteases by three different Pseudomonas strains, whereas Nicodème et al. (19) showed that Pseudomonas sp. LBSA1 isolated from raw milk produced only one extracellular protease. The majority of Pseudomonas species, and other psychrotrophs, produce a single type of monomeric (40-55 kDa) neutral metalloprotease, with optimum $\mathrm{pH}$ of 6.5-8.0 (3,20,26).

Proteolytic activities detected on skim milk broth are of particular concern, since these enzymes could be produced during the cold storage of raw milk and contribute to the 
spoilage of milk after heat treatment. The casein content and $\mathrm{pH}$ of normal milk were shown to be suitable for the action of proteases produced by psychrotrophs isolated from raw milk (20,25). Actually, casein hydrolysis results in the destabilization of the casein micelle and the production of small peptides that contribute to bitter flavors in milk and milk products $(6,12)$. Proteolysis is a main factor limiting the shelflife of UHT milk due to flavor and texture changes, with the eventual formation of a gel. This process is of special economical importance since only trace levels of protease are required to cause gelation of UHT milk during storage (5).

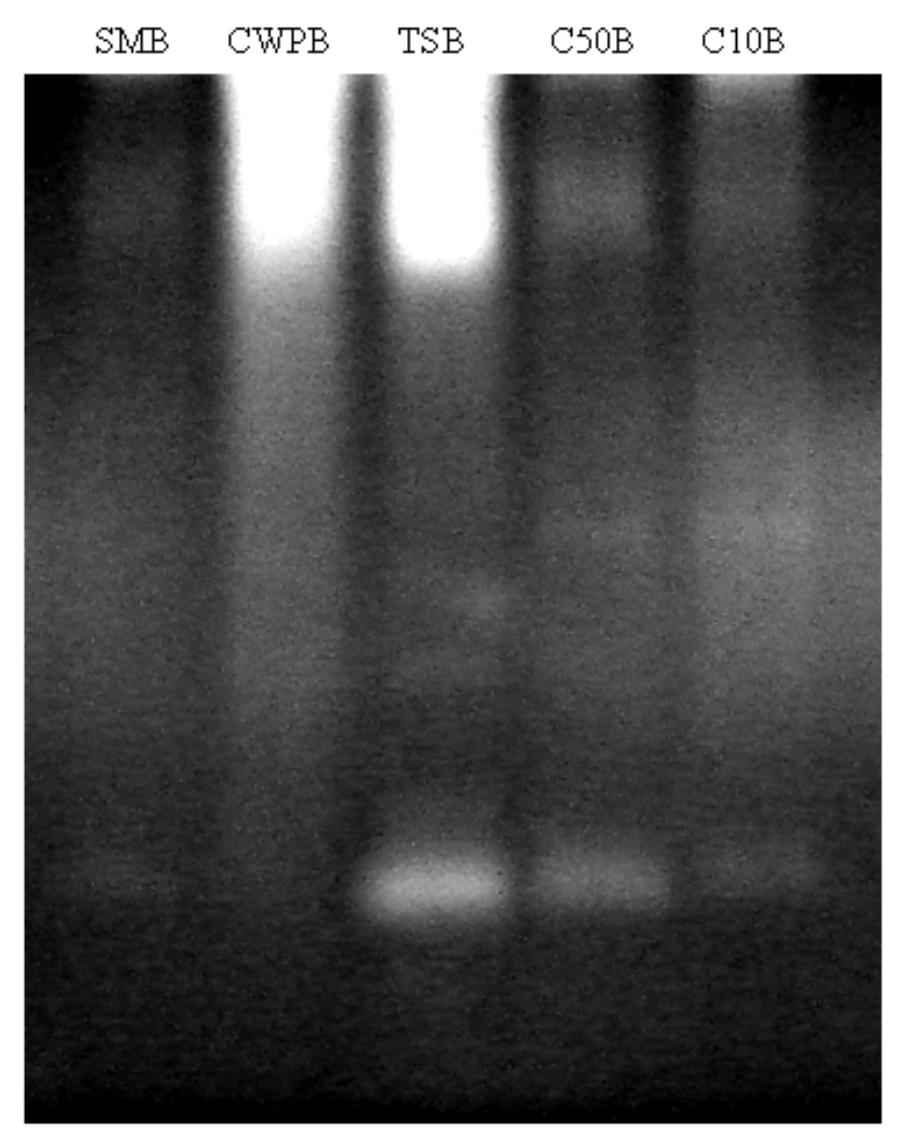

Figure 1. Gelatin zymogram of Pseudomonas sp. culture supernatants. This strain was grown on skim milk broth (SMB), cheese whey powder broth (CWPB), tryptone soy broth (TSB), casein $50 \mathrm{~g} / \mathrm{L}$ broth (C50B) and casein $10 \mathrm{~g} / \mathrm{L}$ broth $(\mathrm{C} 10 \mathrm{~B})$.
Exploitation of Pseudomonas spp. as promising enzyme producers is a reality $(10,15)$. As Pseudomonas $1 \mathrm{~A} 4 \mathrm{R}$ produced high protease levels in TSB and CWPB, investigations on the applications of such proteolytic enzymes are pertinent. In addition, the genus Pseudomonas is considered as an important lipase producer, being biotechnologically exploited (10). Pseudomonas 1A4R showed higher lipolytic activity on CWPB, followed by SMB. Milk is a good medium for lipase production, since the synthesis of such enzymes can be stimulated by lipids, such as milkfat (3). In this sense, lipase activity is generally higher in whole milk than in skimmed milk (6). Contrarily, low levels of lipase were produced on TSB and casein media (Table 1), indicating that the production of lipase is induced by lipids present in culture media.

In milk, lipase activity leads to spoilage through the hydrolysis of triglycerides, with the preferential release of medium and short-chain fatty acids. The hydrolysis of as little as $1 \%$ of the milk triglycerides could lead to rancid off-flavors $(3,12)$. Specifically, Dogan and Boor (7) reported that of 338 Pseudomonas spp. isolated from raw and pasteurized milk, $67 \%$ were lipase positive, and rancid flavors were associated with the presence of lipase-producing strains. As lipases can cause spoilage of milk and dairy products even at low concentrations (1), the production of such enzymes by Pseudomonas 1A4R might negatively affect the quality of milk and dairy products.

Among the extracellular glycosidases investigated, Pseudomonas $1 \mathrm{~A} 4 \mathrm{R}$ produced only high $\alpha$-glucosidase activity in SMB medium. In the remaining culture media, glycosidases were produced only at low levels or were not produced at all (Table 1). Contrarily, the hydrolysis of $\beta$-anomers of glucose and galactose by psychrotrophic bacteria was reported to occur more rapidly than their respective $\alpha$-anomers (15). Deeth et al. (6) observed the production of $\beta$-galactosidase by Pseudomonas spp. in both skim and whole milk. However, production of $\alpha$-glycosidases was not studied by those authors. Marin et al. (16) reported that P. fluorescens was able to 
release monosaccharides (such as glucose, galactose and $\mathrm{N}$ acetylglucosamine) from glycoproteins of skim milk, washedcream buttermilk and milk fat globule membrane (MFGM). The release of monosaccharides, observed during the storage of UHT milk, might indicate the presence of glycosidase activities produced by psychrotrophics (2,23). These extracellular enzymes might play an important role in the shelf-life of milk and dairy products, since the hydrolysis of glycoconjugates may render the non-carbohydrate portion of a molecule accessible to specific hydrolases $(6,16)$.

Microbial contamination of raw milk is a crucial event determining the quality of the fluid milk and milk products. The main sources of bacterial contamination of raw milk are the interior of the udder, cows' teats, and the milking, storage and transporting equipments $(3,18)$. As different bacterial strains yield different levels of enzymes with different stabilities, the identification of spoilage bacteria is important (3). The results obtained in SMB are of particular interest, since such enzymes might be produced by Pseudomonas $1 \mathrm{~A} 4 \mathrm{R}$ during the cold storage of raw milk, and subsequently act on the three major components of milk (proteins, lipids and carbohydrates), leading to a potential spoilage of this product and its derivatives.

\section{ACKNOWLEDGMENTS}

This work was supported by CAPES and CNPq (Brazil).

\section{REFERENCES}

1. Abdou, A.M. (2003). Purification and partial characterization of psychrotrophic Serratia marcescens lipase. J. Dairy Sci. 86, 127-132.

2. Belloque, J.; Villamiel, M.; López-Fandiño, R.; Olano, A. (2001). Release of galactose and $\mathrm{N}$-acetylglucosamine during the storage of UHT milk. Food Chem. 72, 407-412.

3. Chen, L.; Daniel, R.M.; Coolbear, T. (2003). Detection and impact of protease and lipase activities in milk and milk powders. Int. Dairy J. 13, 255-275.

4. Daroit, D.J.; Simonetti, A.; Hertz, P.F.; Brandelli, A. (2008). Purification and characterization of an extracellular $\beta$-glucosidase from Monascus purpureus. J. Microbiol. Biotechnol. 18, 933-941.

5. Datta, N.; Deeth, H.C. (2003). Diagnosing the cause of proteolysis in UHT milk. LWT - Food Sci. Technol. 36, 173-182.

6. Deeth, H.C.; Khusniati, T.; Datta, N.; Wallace, R.B. (2002). Spoilage patterns of skim and whole milks. J. Dairy Res. 69, 227-241.

7. Dogan, B.; Boor, K.J. (2003). Genetic diversity and spoilage potentials among Pseudomonas spp. isolated from fluid milk products and dairy processing plants. Appl. Environ. Microbiol. 69, 130-138.

8. Eneroth, A.; Christiansson, A.; Brendehaug, J.; Molin, G. (1998). Critical contamination sites in the production line of pasteurised milk, with reference to the psychrotrophic spoilage flora. Int. Dairy J. 8, 829-834.

9. Gram, L.; Ravn, L.; Rasch, M.; Bruhn, J.B.; Christensen, A.B.; Givskov, M. (2002). Food spoilage - interactions between food spoilage bacteria. Int. J. Food Microbiol. 78, 79-97.

10. Gupta, R.; Gupta, N.; Rathi, P. (2004). Bacterial lipases: an overview of production, purification and biochemical properties. Appl. Microbiol. Biotechnol. 64, 763-781.

11. Holtz, J.G.; Krieg, N.R.; Sneath, P.H.A.; Staley, J.T.; Williams, S.T. (2000). Bergey's manual of determinative bacteriology, $9^{\text {th }}$ edition. Lippincott Williams \& Wilkins, Philadelphia, PA.

12. Huis in't Veld, J.H.J. (1996). Microbial and biochemical spoilage of foods: an overview. Int. J. Food Microbiol. 33, 1-18.

13. Kwon, S.W.; Kim, J.S.; Park, I.C.; Yoon, S.H.; Park, D.H.; Lim, C.K.; Go, S.J. (2003). Pseudomonas koreensis sp. nov. and Pseudomonas jinjuensis sp. nov., novel species from farm soils in Korea. Int. J. Syst. Evol. Microbiol. 53, 21-27.

14. MacFaddin, J.F. (2000). Biochemical tests for identification of medical bacteria, $3^{\text {rd }}$ edition. Lippincott Williams \& Wilkins, Baltimore, PA.

15. Marin, A.; Marshall, R.T. (1983). Production of glycosidases by psychrotrophic bacteria. J. Food Sci. 48, 570-573.

16. Marin, A.; Mawhinney, T.P.; Marshall, R.T. (1984) Glycosidic activities of Pseudomonas fluorescens on fat-extracted skim milk, buttermilk, and milk fat globule membranes. J. Dairy Sci. 67, 52-59.

17. Martins, M.L.; Pinto, C.L.O.; Rocha, R.B.; Araújo, E.F.; Vanetti, M.C.D. (2006). Genetic diversity of Gram-negative, proteolytic, psychrotrophic bacteria isolated from refrigerated raw milk. Int. J. Food Microbiol. 111, 144-148.

18. Munsch-Alatossava, P.; Alatossava, T. (2006). Phenotypic characterization of raw milk-associated psychrotrophic bacteria. Microbiol. Res. 161, 334-346.

19. Nicodème, M.; Grill, J.P.; Humbert, G.; Gaillard, J.L. (2005). Extracellular protease activity of different Pseudomonas strains: dependence of proteolytic activity on culture conditions. J. Appl. Microbiol. 99, 641-648.

20. Nielsen, S.S. (2002). Plasmin system and microbial proteases in milk: 
characteristics, roles, and relationship. J. Agric. Food Chem. 50, 66286634.

21. Nörnberg, M.F.B.L.; Tondo, E.C.; Brandelli. A. (2009) Psychrotrophic bacteria and proteolytic activity in refrigerated raw milk. Acta Sci. Vet. 37, 157-163.

22. Rajmohan, S.; Dodd, C.E.R.; Waites, W.M. (2002). Enzymes from isolates of Pseudomonas fluorescens involved in food spoilage. J. Appl. Microbiol. 93, 205-213.

23. Recio, M.I.; Villamiel, M.; Martínez-Castro, I.; Olano, A. (1998). Changes in free monosaccharides during storage of some UHT milks: a preliminary study. Eur. Food Res. Technol. 207, 180-181.

24. Riffel, A.; Brandelli, A. (2006). Keratinolytic bacteria isolated from feather waste. Braz. J. Microbiol. 37, 395-399.

25. Sorhaug, T.; Stepaniak, L. (1997). Psychrotrophs and their enzymes in milk and dairy products: quality aspects. Trends Food Sci. Technol. 8, 35-
41.

26. Stepaniak, L. (2004). Dairy enzymology. Int. J. Dairy Technol. 57, 153171.

27. Thompson, J.D.; Higgins, D.G.; Gibson, T.J. (1994). CLUSTALW: improving the sensitivity of progressive multiple sequence alignment through sequence weighting, position-specific gap penalties and weight matrix choice. Nucleic Acids Res. 22, 4673-4680.

28. Tvrzová, L.; Schumann, P.; Spröer, C.; Sedlácek, I.; Pácová, Z.; Sedo, O.; Zdráhal, Z., Steffen, M.; Lang, E. (2006). Pseudomonas moraviensis sp. nov. and Pseudomonas vranovensis sp. nov., soil bacteria isolated on nitroaromatic compounds, and emended description of Pseudomonas asplenii. Int. J. Syst. Evol. Microbiol. 56, 2657-2663.

29. Wiedmann, M.; Weilmeier, D.; Dineen, S.S.; Ralyea, R., Boor, K.J. (2000). Molecular and phenotypic characterization of Pseudomonas spp. isolated from milk. Appl. Environ. Microbiol. 66, 2085-2095. 